\title{
Antimutagenic and antioxidant activity of novel 4-substituted phenyl-2,2'-bichalcophenes and aza-analogs
}

This article was published in the following Dove Press journal:

Drug Design, Development and Therapy

5 February 2013

Number of times this article has been viewed

\author{
Wael M El-Sayed ${ }^{1,2}$ \\ Warda A Hussin ${ }^{3}$ \\ 'King Faisal University, Faculty of \\ Science, Departments of Biological \\ Sciences and Chemistry, Al-Hufof, \\ Ahsa, Kingdom of Saudi Arabia; \\ ${ }^{2}$ University of Ain Shams, Faculty \\ of Science, Department of Zoology, \\ Cairo, Egypt; ${ }^{3} \mathrm{Al}-\mathrm{Azh}$ r University, \\ Faculty of Science, Department of \\ Botany and Microbiology, Cairo, Egypt
}

\begin{abstract}
Evaluation of the potential antimutagenic activities of new compounds by Ames assay has been of great interest for the development of novel therapeutics for many diseases including cancer. Ten novel bichalcophenes with in vitro and in vivo broad spectrum activities against various microbial strains were investigated throughout the present study for their cytotoxic, antioxidant, and antimutagenic potential in a Salmonella reverse mutation assay system against sodium azide $\left(\mathrm{NaN}_{3}\right)$ and benzo[a]pyrene $(\mathrm{B}[\mathrm{a}] \mathrm{P})$. At nontoxic concentrations, all bichalcophenes alone or in combination with $\mathrm{NaN}_{3}(1 \mu \mathrm{g} /$ plate $)$ or $\mathrm{B}[\mathrm{a}] \mathrm{P}(20 \mu \mathrm{M})$ with S9 mix were not mutagenic. The bichalcophenes significantly reduced $\mathrm{NaN}_{3}$ - and $\mathrm{B}[\mathrm{a}] \mathrm{P}$-induced mutagenicity under pre-exposure and co-exposure conditions in a concentration-independent manner. However, the antimutagenic activity of bichalcophenes against $\mathrm{B}[\mathrm{a}] \mathrm{P}$ varied depending on the exposure regimen, being more effective under pre-exposure conditions. The antimutagenic activity was correlated with a high antioxidant activity that could promote the DNA repair system. Bichalcophenes are least likely to interfere with the microsomal bioactivation of B[a]P. Monocationic bichalcophenes were superior to the corresponding mononitriles as antimutagenic agents against both mutagens investigated, possibly due to the higher nucleophilic centers they have which could bind and protect the bacterial DNA. Three monocationic compounds were shown to have a strong anticancer activity against the 58 cell line. Based on the results of the present investigation, monocationic compounds $(1,4$, and $5 \mathrm{~B})$ will be selected for further time consuming and costly chemoprevention studies in animal models.
\end{abstract}

Keywords: bichalcophenes, Salmonella typhimurium, sodium azide, benzo[a]pyrene, antimutagenicity

\section{Introduction}

Human exposure to genotoxic substances present in food and the environment is inevitable. Therefore, humans are provided with many defenses. The failure of these defenses could lead to DNA damage and failure of repair systems, leading to cancer. Novel potential drugs are usually screened for their possible mutagenic/antimutagenic activities in many systems including the Salmonella typhimurium microsome assay. This fruitful assay is very efficient in screening for anticancer activities of novel compounds and proved a strong relation between the mutagenicity in Salmonella and the carcinogenicity in animal models. ${ }^{1}$

Several pentamidine derivatives have antiproliferative activity against several human cancer cell lines. ${ }^{2,3}$ However, these exhibit a number of serious side effects, toxicity problems, and poor availability. ${ }^{4}$ Recently, a series of pentamidine-related 4-substituted phenyl bichalcophenes and aza-analogs (Figure 1) were synthesized, ${ }^{5}$
Correspondence: Wael M El-Sayed University of Ain Shams, Faculty of Science, Department of Zoology, Abbassia, II 566, Cairo, Egypt

Tel +2 224821633

Fax +2 226842123

Email waelelhalawany@hotmail.com 
<smiles>N#Cc1ccc(-c2ccc(-c3ccco3)o2)cc1</smiles><smiles>N=C(N)c1ccc(-c2ccc(-c3ccco3)o2)cc1</smiles><smiles>N#Cc1ccc(-c2ccc(-c3ccco3)o2)nc1</smiles><smiles>N=C(N)c1ccc(-c2ccc(-c3ccco3)o2)nc1</smiles><smiles>N#Cc1ccc(-c2ccc(-c3cccs3)o2)cc1</smiles>

$3 A$

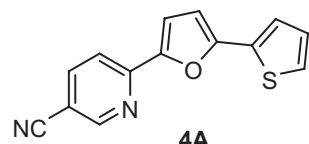

$4 \mathrm{~A}$

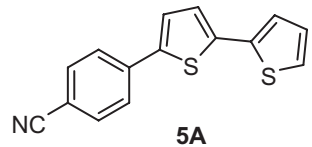

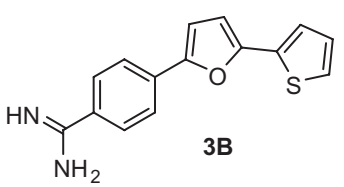
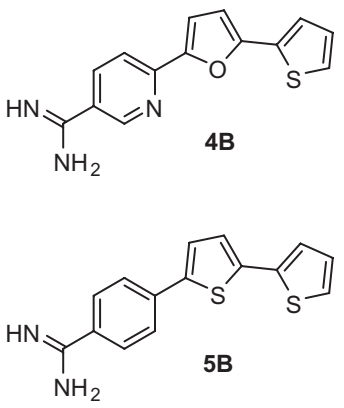

Figure I 4-substituted phenyl-2,2'-bichalcophenes and aza-analogs.

and shown to exhibit structurally related broad-spectrum antimicrobial activities against Gram positive and Gram negative bacteria. ${ }^{6}$ In addition, these novel bichalcophenes were not toxic to the mouse hepa1c1c7 cells up to $200 \mu \mathrm{M}$ and the $\mathrm{IC}_{50}$ values were $>450 \mu \mathrm{M}$ suggesting their possible clinical use. Two of these bichalcophenes (designated as $1 \mathrm{~A}$ and $1 \mathrm{~B}$ in the present study) were found to elevate the enzymatic and non-enzymatic antioxidants in mice and caused a conversion of methicillin-resistant bacteria into methicillin-susceptible bacteria. ${ }^{7}$

We pursued an investigation of antimutagenic activities of novel bichalcophenes and aza-analogs against two mutagens that act in different ways: (1) sodium azide $\left(\mathrm{NaN}_{3}\right)$ which is a powerful direct mutagen that does not require a metabolic activation; and (2) benzo[a]pyrene (B[a]P), a known ubiquitous environmental carcinogen, which is one of the polycyclic aromatic hydrocarbons that needs metabolic activation mainly by cytochrome P4501A1. ${ }^{8}$ Benzo[a]pyrenediolepoxide and bibenzo[a,1]pyrene are the major metabolites of $\mathrm{B}[\mathrm{a}] \mathrm{P}$ responsible for cancer. ${ }^{9,10}$ The mutagenic activity of $\mathrm{NaN}_{3}$ and $\mathrm{B}[\mathrm{a}] \mathrm{P}$ were inhibited by the addition of several antioxidants. ${ }^{10-13}$ Therefore, we conducted this study to evaluate the antimutagenic and antioxidant activities of novel bichalcophenes using the Salmonella

reverse mutation assay system against $\mathrm{NaN}_{3}$ and $\mathrm{B}[\mathrm{a}] \mathrm{P}$ as a prelude to the time consuming and costly in vivo evaluation of anticancer properties of these compounds.

\section{Materials and methods}

The S. typhimurium TA1535, a histidine-mutant bacterial strain was obtained from the American Type Culture Collection (Manassas, VA, USA). $\mathrm{NaN}_{3}, \mathrm{~B}[\mathrm{a}] \mathrm{P}$, and nicotinamide adenine dinucleotide phosphate reduced (NADPH) were obtained from Sigma-Aldrich (St Louis, MO, USA). Ten bichalcophene derivatives (Figure 1) were kindly provided by Professor MA Ismail to be used throughout the present study. The S9 mix consisted of filter-sterilized NADPH (1.25 mM) and hepatic $\mathrm{S} 9$ fraction (4 $\mathrm{mg}$ protein $/ \mathrm{mL}$ ) prepared from male Sprague Dawley rats treated with a single dose $(25 \mathrm{mg} / \mathrm{kg}$, intraperitoneal in corn oil) of Aroclor 1254 for three days.

\section{Cytotoxicity assays}

The cytotoxicity assays were performed using two exposure conditions: bacterial growth in broth and bacterial colony growth on nutrient agar plates. In the former, an overnight growing S. typhimurium TA1535 was grown in Oxoid Nutrient Broth No 2 in 96-well plates in the presence and absence of bichalcophenes $(12.5-100 \mu \mathrm{M})$ for 15 hours at $37^{\circ} \mathrm{C}$. The final optical density of each well was recorded at $570 \mathrm{~nm}$. In the latter, the experiment was designed with conditions that mimic those of the revertant mutagenesis/antimutagenesis assay. A preliminary experiment was performed to identify the optimal bacterial dilution using three dilutions $\left(10^{-6}, 10^{-7}\right.$, and $\left.10^{-8}\right)$. A $10^{-7}$ dilution was the appropriate dilution; therefore, it was selected to proceed with. Briefly, $100 \mu \mathrm{L}$ of $10^{-7}$ dilution of the overnight growing bacterial culture in Luria Broth medium was incubated with each of the bichalcophenes $(0,5,10$, and $20 \mu \mathrm{M})$ and mixed with $2.5 \mathrm{~mL}$ of warm $0.6 \%$ top agar ( $\mathrm{NaCl} /$ agar). The mix was then added to nutrient agar plates and the plates were incubated at $37^{\circ} \mathrm{C}$ for 24 hours. After the incubation period, colonies on triplicate plates were counted and compared to control plates containing no bichalcophenes. Concentrations investigated hereafter for all bichalcophenes were 10 and $20 \mu \mathrm{M}$ except for compounds $1 \mathrm{~B}$ and $5 \mathrm{~B}$, in which the concentrations used were 5 and $10 \mu \mathrm{M}$.

\section{Bichalcophenes cytotoxicity in combination with selected mutagens}

To rule out the possible toxic effect exerted by a combination of the mutagens used and bichalcophene derivatives in the mutagenicity/antimutagenicity evaluation assays, an evaluation 
of the number of colonies/plate was performed. A $100 \mu \mathrm{L}$ sample of $10^{-7}$ dilution of overnight growing $S$. typhimurium TA1535 was incubated with each bichalcophene at $37^{\circ} \mathrm{C}$ for 30 minutes on a shaking incubator in the presence of $1 \mu \mathrm{g} /$ plate of $\mathrm{NaN}_{3}$ or $20 \mu \mathrm{M}$ of $\mathrm{B}[\mathrm{a}] \mathrm{P}$ and $\mathrm{S} 9 \mathrm{mix}$ in $400 \mu \mathrm{L}$ of phosphate buffer. Control experiments were carried out simultaneously - the S9 mix alone had no effect on the bacterial viability. Colonies on triplicate plates were counted after 24 hours.

\section{Mutagenicity assays}

The Ames Salmonella/microsome mutagenicity assay was performed for screening the mutagenic potential of the bichalcophenes as described elsewhere. ${ }^{1}$ Briefly, $100 \mu \mathrm{L}$ of 15-hour overnight growing $S$. typhimurium TA1535 $\left(1 \times 10^{9}\right.$ colony forming units $/ \mathrm{mL}$ ) in Luria Broth medium was pre-incubated with each bichalcophene within the non-toxic range of concentrations at $37^{\circ} \mathrm{C}$ for 30 minutes in phosphate buffer $(\mathrm{pH} 7.4)$ in the presence of $\mathrm{S} 9$ mix. The incubate $(0.6 \mathrm{~mL})$ was then added to top agar containing a growth-initiating concentration $(50 \mu \mathrm{M})$ of histidine/biotin, and poured on to minimal glucose agar plates. Revertant colonies were counted after incubation at $37^{\circ} \mathrm{C}$ for 48 hours. Spontaneous revertant colonies arising on plates containing neither mutagens nor bichalcophenes were also counted. Revertant colonies seen with $20 \mu \mathrm{M} \mathrm{B}[\mathrm{a}] \mathrm{P}$ with $\mathrm{S} 9$ mix were used as a positive control. All assays were performed in triplicates.

\section{Antimutagenicity assays}

For assessing the antimutagenic properties of bichalcophenes against $\mathrm{NaN}_{3}$ or $\mathrm{B}[\mathrm{a}] \mathrm{P}$, pre-exposure and co-exposure assays were carried out simultaneously by a modified method of Maron and Ames. ${ }^{1}$ Under pre-exposure conditions, each bichalcophene was incubated with $S$. typhimurium TA1535 at $37^{\circ} \mathrm{C}$ for 30 minutes before the addition of $\mathrm{B}[\mathrm{a}] \mathrm{P}(20 \mu \mathrm{M})$ or $\mathrm{NaN}_{3}$ ( $1 \mu \mathrm{g} /$ plate). Co-exposure assays were performed by incubating the bacteria, the mutagen, and each bichalcophene together at $37^{\circ} \mathrm{C}$ for 30 minutes prior to plating on minimal glucose agar plates. In all assays, positive and negative controls were used. All antimutagenesis determinations were performed in triplicate. Revertant colonies were counted after 48 hours of incubation and the antimutagenic potential of the tested compounds was expressed as a percentage of reduction in mutagenicity, ${ }^{14}$ and calculated according to the following equation:

$\%$ reduction in mutagenicity $=([\mathrm{Rm}-\mathrm{Rs}]-[\mathrm{Ra}-\mathrm{Rs}] /$

$$
[\mathrm{Rm}-\mathrm{Rs}]) \times 100
$$

where $\mathrm{Rm}$ is the number of revertants/plate in the presence of mutagen; Rs is the number of spontaneous revertants/plate; and $\mathrm{Ra}$ is the number of revertants/plate in the presence of bichalcophenes.

A $20 \%$ or less reduction means no antimutagenic activity, $20 \%-40 \%$ reduction means a moderate activity, and $40 \%$ or more reduction means a strong antimutagenic activity.

The mutant frequency or mutation rate was then calculated from the mutant colonies/viable colonies for both exposure conditions for the mutagens investigated. All procedures were approved by the University of King Faisal Committee of Scientific Research Ethics.

\section{Determination of total antioxidant activity}

The antioxidant capacity of bichalcophenes was measured spectrophotometrically using a phosphomolybdenum method, ${ }^{15}$ based on the reduction of $\mathrm{Mo}(\mathrm{VI})$ to $\mathrm{Mo}(\mathrm{V})$ and the subsequent formation of specific green phosphate/Mo(V) compounds. A $0.3 \mathrm{~mL}$ aliquot of sample solution $(20 \mu \mathrm{M}$ final concentration) was combined with $2.7 \mathrm{~mL}$ of the reagent solution (0.6 M sulfuric acid, $28 \mathrm{mM}$ sodium phosphate, and $4 \mathrm{mM}$ ammonium molybdate). The sample was capped and incubated in a boiling water bath at $95^{\circ} \mathrm{C}$ for 90 minutes. After cooling to room temperature, the absorbance was measured at $695 \mathrm{~nm}$. Stock solution of ascorbate was freshly prepared and used as a standard antioxidant.

\section{Assay of reducing power}

The reducing power of bichalcophenes was determined according to the method described by Oyaizu. ${ }^{16}$ The samples (20 $\mu \mathrm{M}$ final concentration) were mixed with $2.5 \mathrm{~mL}$ of phosphate buffer $(0.2 \mathrm{M}, \mathrm{pH}$ 6.6) and potassium ferricyanide $(2.5 \mathrm{~mL}, 10 \mathrm{~g} / \mathrm{L})$. The mixtures were incubated at $50^{\circ} \mathrm{C}$ for 20 minutes. Trichloroacetic acid $(2.5 \mathrm{~mL}, 10 \%)$ was added to each mixture and centrifuged at $3000 \mathrm{~g}$ for 3 minutes. Finally, the supernatants $(2.5 \mathrm{~mL})$ were mixed with distilled water $(2.5 \mathrm{~mL})$ and $\mathrm{FeCl}_{3}(0.5 \mathrm{~mL}, 0.1 \%)$. The absorbance of the solution was measured at $700 \mathrm{~nm}$. Ascorbate solution was freshly prepared and used as a positive control.

\section{Statistical analysis of data}

Statistical analyses were performed using ANOVA, followed by Fisher's protected least significant difference multiple range test. Differences were considered significant at $P$ values of $<0.05$.

\section{Results and discussion}

In the current study, the mutagenic and antimutagenic properties of novel bichalcophenes against $\mathrm{NaN}_{3}$ and $\mathrm{B}[\mathrm{a}] \mathrm{P}$ were 
investigated using the Salmonella reverse bacterial assay. Since mutation is an early key step in cancer development, the Salmonella reverse assay is of great importance in the detection of mutagenic/carcinogenic and antimutagenic/anticarcinogenic agents in the pipeline of drug discovery and development.

\section{Effect of bichalcophenes on the viability of S. typhimurium}

It was crucial to first examine the effect of bichalcophenes on the viability of bacteria to validate the antimutagenic data and be assured that the reduction in the number of mutant colonies is not due to the inhibition of the growth of bacteria due to overt toxicity. The non-toxic/non-inhibitory concentrations of the tested bichalcophene derivatives against S. typhimurium TA1535 were determined using two independent exposure conditions. In the liquid broth method, with the exception of compounds $1 \mathrm{~B}$ and $5 \mathrm{~B}$, all compounds up to a $100 \mu \mathrm{M}$ had no significant toxic effects on the viability of bacteria (Table 1). Compounds $1 \mathrm{~B}$ and 5B showed a concentration-dependent reduction in the bacterial growth. Compound 1B significantly reduced the viability at 25, 50, and $100 \mu \mathrm{M}$ and compound 5B had a significant cytotoxic effect at 50 and $100 \mu \mathrm{M}$. In a previous study, ${ }^{6}$ the minimum inhibitory concentration (MIC) values of all bichalcophenes were at 32-64 $\mu \mathrm{M}$ against Escherichia coli, another Gram negative bacteria. Compounds $1 \mathrm{~B}$ and $5 \mathrm{~B}$ discerned themselves and the MIC values for these compounds were 16 and $8 \mu \mathrm{M}$, respectively. It was shown that the monoamidines (B compounds) are more active as antibacterial agents than the corresponding mononitriles (A compounds) and the

Table I Cytotoxicity of bichalcophenes to Salmonella typhimurium TAI535 in liquid medium

\begin{tabular}{|c|c|c|c|c|}
\hline \multirow[t]{2}{*}{ Compound $^{\mathrm{a}}$} & \multicolumn{4}{|c|}{$\begin{array}{l}\text { Viability at bichalcophene concentrations } \\
\text { (\% of growth) }\end{array}$} \\
\hline & $12.5 \mu \mathrm{M}$ & $25 \mu \mathrm{M}$ & $50 \mu \mathrm{M}$ & $100 \mu \mathrm{M}$ \\
\hline IA & $100.1 \pm 10.1$ & $105.5 \pm 6.6$ & $107.9 \pm 7.6$ & $112.8 \pm 11.4$ \\
\hline IB & $79.1 \pm 2.6$ & $59.4 \pm 3.7^{b}$ & $46.5 \pm 3.4^{b}$ & $40.8 \pm 2.5^{b}$ \\
\hline $2 \mathrm{~A}$ & $139.4 \pm 11.2^{b}$ & $124.7 \pm 10.1$ & $111.3 \pm 10.1$ & $101.2 \pm 9.7$ \\
\hline $2 B$ & $123.8 \pm 7.7$ & $101.5 \pm 9.0$ & $100.4 \pm 8.9$ & $94.8 \pm 4.8$ \\
\hline $3 \mathrm{~A}$ & $101.2 \pm 6.3$ & $100.0 \pm 8.6$ & $100.0 \pm 7.3$ & $99.1 \pm 8.7$ \\
\hline $3 B$ & $104.4 \pm 9.8$ & $108.2 \pm 7.4$ & $103.3 \pm 5.2$ & $94.7 \pm 6.5$ \\
\hline $4 \mathrm{~A}$ & $134.6 \pm 12.4$ & $129.7 \pm 9.3$ & $127.1 \pm 5.4$ & $116.7 \pm 9.6$ \\
\hline $4 \mathrm{~B}$ & $112.2 \pm 5.0$ & $101.3 \pm 4.4$ & $92.5 \pm 8.0$ & $87.6 \pm 8.7$ \\
\hline $5 \mathrm{~A}$ & $1 I I . I \pm 6.1$ & $110.5 \pm 5.6$ & $119.4 \pm 6.7$ & $108.5 \pm 7.3$ \\
\hline $5 B$ & $92.1 \pm 2.3$ & $80.4 \pm 3.1$ & $64.5 \pm 4.8^{b}$ & $51.4 \pm 3.8^{b}$ \\
\hline
\end{tabular}

Notes: aStructures are shown in Figure I; bsignificantly different $(P<0.05)$ from bacteria grown in the absence of bichalcophenes. The cytotoxicity assays were performed in triplicates and are expressed as \% control (mean \pm SEM).

Abbreviation: SEM, standard error of the mean. presence of thiophene rings as in compound $5 \mathrm{~B}$ adds more activity, while the presence of pyridyl rings (as in compounds $2 \mathrm{~B}$ and $4 \mathrm{~B}$ ) negatively affects activity. ${ }^{6}$ Compound $2 \mathrm{~A}$ at $12.5 \mu \mathrm{M}$ was unique in causing a significant elevation ( $40 \%)$ in the viability of bacteria; whether it acts as a nutrient to the bacteria, a source of nitrogen, or promotes the maximal growth through a different mechanism is unknown. From the previous data and to avoid any cytotoxicity concerns, we decided to reduce the concentrations to 10 and $20 \mu \mathrm{M}$ for all bichalcophenes and 5 and $10 \mu \mathrm{M}$ for compounds $1 \mathrm{~B}$ and $5 \mathrm{~B}$ for the following experiments. In the colony/plate assay, none of the bichalcophene derivatives exhibited any cytotoxicity (diminution in the number of colonies) at 10 and $20 \mu \mathrm{M}$ for all compounds and 5 and $10 \mu \mathrm{M}$ for compounds $1 \mathrm{~B}$ and 5B (Table 2). On the other hand, a significant increase in the number of colonies was recorded with compound $2 \mathrm{~A}$ (193\%) at $10 \mu \mathrm{M}$ and with compound $4 \mathrm{~A}(139 \%)$ at $20 \mu \mathrm{M}$. Compounds $2 \mathrm{~A}$ and $4 \mathrm{~A}$ have similar chemical structures both are mononitrile aza derivatives of bichalcophenes.

\section{Effect of combination of bichalcophenes and mutagens on the viability of S. typhimurium}

Two mutagens were selected for antimutagenic studies: $\mathrm{NaN}_{3}$ and $\mathrm{B}[\mathrm{a}] \mathrm{P}$. Both act through different pathways. $\mathrm{NaN}_{3}$ is a direct mutagen that does not need metabolic activation and $\mathrm{B}[\mathrm{a}] \mathrm{P}$ is a known polycyclic aromatic hydrocarbon that

Table 2 Effect of bichalcophenes on Salmonella typhimurium TAI535 viability as assessed by colony formation on plate

\begin{tabular}{|c|c|c|}
\hline \multirow[t]{2}{*}{ Compound } & \multicolumn{2}{|c|}{$\begin{array}{l}\text { Viability at bichalcophene concentrations } \\
\text { (colonies/plate (\% of control)) }\end{array}$} \\
\hline & $5 / 10 \mu M$ & $10 / 20 \mu \mathrm{M}$ \\
\hline None & \multicolumn{2}{|c|}{$45.7 \pm 2.2(100)$} \\
\hline IA & $54.3 \pm 3.3(119)$ & $45.0 \pm 2.5(98)$ \\
\hline IB & $61.7 \pm 2.7(135)$ & $55.3 \pm 3.6(121)$ \\
\hline $2 \mathrm{~A}$ & $88.3 \pm 5.4(193)^{b}$ & $47.0 \pm 4.5(103)$ \\
\hline $2 B$ & $44.7 \pm 3.6(98)$ & $46.7 \pm 3.2(102)$ \\
\hline $3 \mathrm{~A}$ & $46.7 \pm 4.8(102)$ & $42.3 \pm 1.9(93)$ \\
\hline $3 B$ & $42.7 \pm 4.8(93)$ & $43.3 \pm 2.5(95)$ \\
\hline $4 \mathrm{~A}$ & $41.3 \pm 6.4(90)$ & $63.7 \pm 3.8(139)^{b}$ \\
\hline $4 B$ & $39.7 \pm 4.5(87)$ & $40.0 \pm 2.1(88)$ \\
\hline $5 \mathrm{~A}$ & $40.3 \pm 2.9(88)$ & $45.7 \pm 3.0(100)$ \\
\hline $5 B$ & $4 I .7 \pm 1.8(9 \mid)$ & $41.3 \pm 2.8(90)$ \\
\hline
\end{tabular}

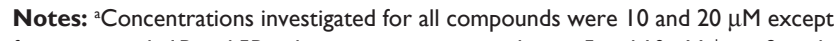
for compounds IB and $5 \mathrm{~B}$ - the concentrations used were 5 and $10 \mu \mathrm{M}$; bsignificantly different $(P<0.05)$ from the number of colonies/plate (mean \pm SEM) recorded in the absence of bichalcophenes. Assays were performed in triplicates with a $10^{-7}$ dilution of an overnight Salmonella typhimurium TAI535.

Abbreviation: SEM, standard error of the mean. 
needs metabolic activation by $\mathrm{P} 4501 \mathrm{~A} 1{ }^{8}$ The $S$. typhimurium TA1535 strain contains the base-pair substitution mutation his $G 46,{ }^{17}$ which is known to be more responsive to sodium azide than other direct mutagens. ${ }^{1}$

To rule out any possible toxic effects developed from the concurrent exposure of bacteria to bichalcophenes and any of the tested mutagens, S. typhimurium TA1535 cells were grown in the presence of either $\mathrm{NaN}_{3}(1 \mu \mathrm{g} /$ plate $)$ or $\mathrm{B}[\mathrm{a}] \mathrm{P}(20 \mu \mathrm{M})$ with $\mathrm{S} 9 \mathrm{mix}$ alone or in combination with non-toxic concentrations of the bichalcophenes. None of the bichalcophenes were toxic when used in combination with $\mathrm{NaN}_{3}$ (Table 3). A statistically significant increase in the number of colonies was observed by a combination of compound $1 \mathrm{~B}$ with $\mathrm{NaN}_{3}$ at $5 \mu \mathrm{M}$. When bacteria were exposed to B[a]P, S9 mix and bichalcophenes and evaluated for colony formation the results were similar to those seen with bichalcophenes alone and the number of colonies were not affected reflecting the nontoxic effects of the combination (Table 4) and validating the results of the latter experiments.

\section{Mutagenicity of bichalcophenes}

On examining the mutagenic activity at or well below the non-toxic concentrations, none of the bichalcophenes caused a doubling in the number of colonies over the spontaneous

Table 3 Effect of bichalcophenes and sodium azide $\left(\mathrm{NaN}_{3}\right)$ on Salmonella typhimurium TAI535 viability as assessed by colony formation on plate

\begin{tabular}{|c|c|c|}
\hline \multirow[t]{2}{*}{ Compound } & \multicolumn{2}{|c|}{$\begin{array}{l}\text { Viability at } \mathrm{NaN}_{3} \text { and bichalcophene } \\
\text { concentrations }^{\mathrm{a}} \\
\text { (colonies/plate (\% of control)) }\end{array}$} \\
\hline & $5 / 10 \mu M$ & $10 / 20 \mu \mathrm{M}$ \\
\hline None & \multicolumn{2}{|c|}{$35.0 \pm 3.1(100)$} \\
\hline $\mathrm{NaN}_{3}(\mathrm{I} \mu \mathrm{g} /$ plate $)$ & \multicolumn{2}{|c|}{$36.9 \pm 4.3(105)$} \\
\hline IA & $33.3 \pm 3.0(95)$ & $36.0 \pm 1.8(103)$ \\
\hline IB & $53.0 \pm 1.9(15 I)^{b}$ & $48.7 \pm 4.0(139)$ \\
\hline $2 \mathrm{~A}$ & $36.7 \pm 3.2(105)$ & $44.3 \pm 3.7(127)$ \\
\hline $2 B$ & $33.0 \pm 2.5(94)$ & $37.7 \pm 2.7(108)$ \\
\hline $3 A$ & $49.3 \pm 2.8(|4|)$ & $47.7 \pm 3.0(136)$ \\
\hline $3 B$ & $30.7 \pm 2.7(88)$ & $32.7 \pm 3.1(93)$ \\
\hline $4 \mathrm{~A}$ & $29.7 \pm 2.6(85)$ & $34.3 \pm 2.9(98)$ \\
\hline $4 B$ & $40.0 \pm 3.7(\mathrm{I} \mid 4)$ & $38.7 \pm 3.5(I I I)$ \\
\hline $5 A$ & $42.0 \pm 4.0(120)$ & $43.7 \pm 3.9(125)$ \\
\hline $5 B$ & $34.3 \pm 3.3(98)$ & $30.3 \pm 1.7(87)$ \\
\hline \multicolumn{3}{|c|}{ 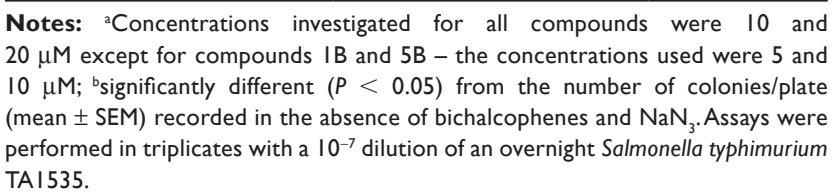 } \\
\hline
\end{tabular}

Table 4 Effect of bichalcophenes, benzo[a]pyrene (B[a]P), and S9 mix on Salmonella typhimurium TAI 535 viability as assessed by colony formation on plate

\begin{tabular}{|c|c|c|}
\hline \multirow[t]{2}{*}{ Compound } & \multicolumn{2}{|c|}{$\begin{array}{l}\text { Viability at } \mathrm{B}[\mathrm{a}] \mathrm{P} \text { and bichalcophene } \\
\text { concentrations }^{\mathrm{a}} \\
\text { (colonies/plate (\% of control)) }\end{array}$} \\
\hline & $5 / 10 \mu \mathrm{M}$ & $10 / 20 \mu \mathrm{M}$ \\
\hline None & \multicolumn{2}{|c|}{$63.0 \pm 5.9(100)$} \\
\hline $\mathrm{B}[\mathrm{a}] \mathrm{P}(20 \mu \mathrm{M})$ & \multicolumn{2}{|c|}{$67.9 \pm 4.7(108)$} \\
\hline IA & $62.3 \pm 4.1$ (99) & $64.7 \pm 5.1(103)$ \\
\hline IB & $63.0 \pm 5.9(100)$ & $64.3 \pm 3.7(102)$ \\
\hline $2 \mathrm{~A}$ & $60.0 \pm 3.8(95)$ & $61.0 \pm 2.1(97)$ \\
\hline $2 B$ & $65.0 \pm 3.9(103)$ & $62.0 \pm 4.8(98)$ \\
\hline $3 \mathrm{~A}$ & $64.7 \pm 4.0(103)$ & $65.0 \pm 2.9(103)$ \\
\hline $3 B$ & $60.7 \pm 4.4(96)$ & $59.7 \pm 4.7(95)$ \\
\hline $4 \mathrm{~A}$ & $64.7 \pm 5.7(103)$ & $64.3 \pm 3.0(102)$ \\
\hline $4 B$ & $67.3 \pm 5.0(107)$ & $61.3 \pm 5.0(97)$ \\
\hline $5 \mathrm{~A}$ & $65.3 \pm 4.5(104)$ & $66.0 \pm 4.8(105)$ \\
\hline $5 B$ & $62.7 \pm 2.9(100)$ & $59.3 \pm 4.0(94)$ \\
\hline
\end{tabular}

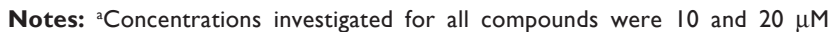
except for compounds IB and $5 \mathrm{~B}$ - the concentrations used were 5 and $10 \mu \mathrm{M}$. No significant changes in the viability of Salmonella typhimurium TAI535 treated with bichalcophenes, $\mathrm{B}[\mathrm{a}] \mathrm{P}$, and $\mathrm{S} 9 \mathrm{mix}$ when compared to non-treated bacteria. Assays were performed in triplicates with a $10^{-7}$ dilution of an overnight bacteria.

number in the presence of S9 mix (Table 5); ie, all of the bichalcophenes were not mutagenic. The experiment was repeated in the absence of S9 mix and very similar results were obtained (data not shown). Similar compounds such as pentamidine derivatives, in spite of their binding to DNA

Table 5 Determination of mutagenic activity of bichalcophenes in Salmonella typhimurium TAI535 in presence of S9 mix

\begin{tabular}{|c|c|c|}
\hline \multirow[t]{2}{*}{ Compound $^{a}$} & \multicolumn{2}{|c|}{$\begin{array}{l}\text { Bichalcophene mutagenicity } \\
\text { (revertant colonies/plate; mean } \pm \text { SEM) }\end{array}$} \\
\hline & $5 / 10 \mu \mathrm{M}$ & $10 / 20 \mu \mathrm{M}$ \\
\hline None (spontaneous) & \multicolumn{2}{|c|}{$27.7 \pm 2.3$} \\
\hline $\mathrm{B}[\mathrm{a}] \mathrm{P}(20 \mu \mathrm{M})$ & \multicolumn{2}{|c|}{$347.7 \pm 33.9^{\mathrm{b}}$} \\
\hline IA & $13.3 \pm 1.5$ & $23.7 \pm 2.5$ \\
\hline IB & $14.0 \pm 2.0$ & $11.3 \pm 1.0$ \\
\hline $2 \mathrm{~A}$ & $29.7 \pm 3.2$ & $23.7 \pm 2.5$ \\
\hline $2 B$ & $14.3 \pm 2.1$ & $16.7 \pm 1.9$ \\
\hline $3 \mathrm{~A}$ & $15.3 \pm 4.2$ & $24.7 \pm 2.5$ \\
\hline $3 B$ & $11.7 \pm 1.5$ & $13.7 \pm 1.5$ \\
\hline $4 \mathrm{~A}$ & $28.7 \pm 3.1$ & $34.0 \pm 3.0$ \\
\hline $4 B$ & $30.3 \pm 3.5$ & $24.0 \pm 2.7$ \\
\hline $5 \mathrm{~A}$ & $15.3 \pm 1.5$ & $26.7 \pm 2.1$ \\
\hline $5 B$ & $15.7 \pm 2.0$ & $13.0 \pm 2.0$ \\
\hline
\end{tabular}

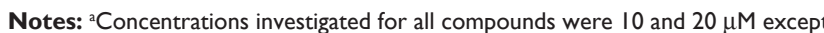
for compounds IB and $5 \mathrm{~B}$, the concentrations used were 5 and $10 \mu \mathrm{M}$; ${ }^{b}$ significantly different $(P<0.05)$ from non-treated bacteria (spontaneous mutations). No mutagenic activity of bichalcophenes/S9 mix recorded in Salmonella typhimurium TAI535 when compared to non-treated or B[a]P-treated bacteria. Assays were performed in triplicate.

Abbreviation: SEM, standard error of the mean. 
minor grooves, have been shown to cause no mutagenic activity in S. typhimurium strains TA98 and TA100 with and without metabolic activation. ${ }^{18,19}$

\section{Antimutagenic activity of bichalcophenes against $\mathrm{NaN}_{3}$ and $\mathrm{B}[\mathrm{a}] \mathrm{P}$}

The potential antimutagenic activity of bichalcophenes was evaluated using a modified Ames assay in pre-exposure and co-exposure treatments. All bichalcophenes showed strong $(>40 \%)$ antimutagenic activity against the $\mathrm{NaN}_{3}$-induced mutagenicity (Table 6). In a few instances, the reduction in mutagenicity was concentration-dependent. The absence of concentration dependency could reflect a saturation effect. The monocationic bichalcophenes were more effective in reducing the azide-induced mutagenicity than the corresponding mononitriles $(3 \mathrm{~B}>3 \mathrm{~A}$ and $5 \mathrm{~B}>5 \mathrm{~A}$ ). Compound $4 \mathrm{~B}$ was superior to $4 \mathrm{~A}$ only at the pre-exposure regimen while $4 \mathrm{~A}$ was better than $4 \mathrm{~B}$ in reducing the azide-induced mutagenicity at the co-exposure treatment (Table 6).

Upon evaluation of the antimutagenic potential of bichalcophenes against $\mathrm{B}[\mathrm{a}] \mathrm{P}$-induced mutagenicity, compounds $1 \mathrm{~B}$ and $5 \mathrm{~B}$ resulted in significant reductions in the mutagenicity induced by $\mathrm{B}[\mathrm{a}] \mathrm{P}$ in pre-exposure and co-exposure treatments at 5 and $10 \mu \mathrm{M}$ (Table 7). However, Compounds $3 \mathrm{~A}$ and $5 \mathrm{~A}$ failed to reduce the induced mutagenicity and caused no significant reduction in the number of revertant colonies. Pre-exposure was much more effective than the co-exposure protocol. Some of the bichalcophenes were effective only under pre-exposure conditions (2A, 4A, 2B, and 4B) at 10 and $20 \mu \mathrm{M}$. The reductions in mutagenicity were concentration-independent. Compound 1A significantly reduced the mutagenicity in pretreatment experiments only at $20 \mu \mathrm{M}$. Compound $3 \mathrm{~B}$ significantly reduced the mutagenicity in pre-exposure at 10 and $20 \mu \mathrm{M}$ and in co-exposure only at $20 \mu \mathrm{M}$. Again, monocationic bichalcophenes ( $1 \mathrm{~B}, 3 \mathrm{~B}$, and $5 \mathrm{~B})$ were more effective than the corresponding mononitriles (1A, 3A, and $5 \mathrm{~A}$ ) in reducing $\mathrm{B}[\mathrm{a}] \mathrm{P}$-induced mutagenicity (Table 7). Bichalcophenes could exert their antimutagenic activities through various mechanisms. One such mechanism is the direct binding and protection of DNA from the electrophilic mutagens or metabolites, ${ }^{20}$ given that bichalcophenes are nucleophilic. The monocationic bichalcophenes provide more nucleophilic centers than mononitriles which could explain their superior antimutagenic activity. Another mechanism could be the elevation in the antioxidant milieu of the cells thus, promoting the DNA repair systems. ${ }^{21}$ The total antioxidant activity and reducing power of bichalcophenes showed that compounds $1 \mathrm{~B}, 3 \mathrm{~B}$, and $5 \mathrm{~B}$ are in the lead with antioxidant activity of $\sim 30 \%-50 \%$ (Figure 2 ) of that of ascorbic acid at the same concentration. In our previous study, compound $1 \mathrm{~B}$ showed a noticeable antioxidant activity in vivo and elevated the hepatic activities of glutathione reductase and glutathione peroxidase and reduced the elevated hepatic malondialdehyde and serum interleukin- 6 in mice infected with methicillin-resistant

Table 6 Determination of anti-mutagenic activity of bichalcophenes in Salmonella typhimurium TAI535 against sodium azide $\left(\mathrm{NaN}_{3}\right.$; I $\mu \mathrm{g} /$ plate $)$

\begin{tabular}{|c|c|c|c|c|}
\hline \multirow[t]{3}{*}{ Compound $^{\mathrm{a}}$} & \multicolumn{4}{|c|}{$\begin{array}{l}\mathrm{NaN}_{3} \text { mutagenicity at bichalcophene concentrations } \\
\text { (revertant colonies/plate; mean } \pm \mathrm{SEM}\left(\% \text { reduction in } \mathrm{NaN}_{3} \text { mutagenicity)) }\right.\end{array}$} \\
\hline & \multicolumn{2}{|l|}{ Pre-exposure } & \multicolumn{2}{|l|}{ Co-exposure } \\
\hline & $5 / 10 \mu \mathrm{M}$ & $10 / 20 \mu \mathrm{M}$ & $5 / 10 \mu M$ & $10 / 20 \mu \mathrm{M}$ \\
\hline $\mathrm{NaN}_{3}$ & \multicolumn{4}{|c|}{$384.7 \pm 14.7(0)$} \\
\hline IA & $47.0 \pm 3.5(96)^{\mathrm{b}}$ & $48.3 \pm 6.8(96)^{b}$ & $59.7 \pm 9.0(93)^{\mathrm{b}}$ & $28.3 \pm 3.1(102)^{\mathrm{b}, \mathrm{c}}$ \\
\hline IB & $56.7 \pm 8.6(94)^{\mathrm{b}}$ & $61.7 \pm 11.4(92)^{\mathrm{b}}$ & $35.0 \pm 3.0(100)^{b}$ & $27.3 \pm 9.3(102)^{b}$ \\
\hline $2 \mathrm{~A}$ & $53.0 \pm 9.8(95)^{\mathrm{b}}$ & $70.7 \pm 12.9(90)^{b}$ & $39.3 \pm 7.6(99)^{b}$ & $47.3 \pm 6.0(96)^{b}$ \\
\hline $2 B$ & $43.7 \pm 10.4(97)^{b}$ & $51.0 \pm 7.8(95)^{b}$ & $63.0 \pm 7.6(92)^{b}$ & $19.3 \pm 1.5(104)^{\mathrm{b}, \mathrm{c}}$ \\
\hline $3 \mathrm{~A}$ & $47.7 \pm 3.5(96)^{\mathrm{b}}$ & $52.0 \pm 5.0(95)^{\mathrm{b}}$ & $95.0 \pm 4.0(83)^{\mathrm{b}}$ & $42.3 \pm 9.1(98)^{\mathrm{b}, \mathrm{c}}$ \\
\hline $3 B$ & $37.3 \pm 2.1(99)^{b}$ & $33.7 \pm 3.5(100)^{\mathrm{b}, \mathrm{d}}$ & $26.7 \pm 6.7(102)^{\mathrm{b}, \mathrm{d}}$ & $17.3 \pm 2.1(105)^{b}$ \\
\hline $4 \mathrm{~A}$ & $186.3 \pm 14.2(57)^{b}$ & $103.0 \pm 9.2(80)^{\mathrm{b}, \mathrm{c}}$ & $32.3 \pm 4.2(101)^{b}$ & $39.7 \pm 6.0(98)^{\mathrm{b}}$ \\
\hline $4 B$ & $35.0 \pm 4.0(100)^{\mathrm{b}, \mathrm{d}}$ & $35.0 \pm 4.5(100)^{\mathrm{b}, \mathrm{d}}$ & $80.3 \pm 6.1(87)^{b, d}$ & $73.3 \pm 7.9(89)^{\mathrm{b}, \mathrm{d}}$ \\
\hline $5 \mathrm{~A}$ & $61.3 \pm 8.1(92)^{\mathrm{b}}$ & $97.7 \pm 10.2(82)^{\mathrm{b}, \mathrm{c}}$ & $47.0 \pm 3.5(96)^{\mathrm{b}}$ & $32.3 \pm 2.5(101)^{b}$ \\
\hline $5 B$ & $35.7 \pm 3.1(100)^{b}$ & $37.0 \pm 5.3(99)^{\mathrm{b}, \mathrm{d}}$ & $21.3 \pm 6.4(104)^{b, d}$ & $15.3 \pm 3.2(105)^{b}$ \\
\hline
\end{tabular}

Notes: ${ }^{a}$ Concentrations investigated for all compounds were 10 and $20 \mu \mathrm{M}$ except for compounds IB and $5 \mathrm{~B}-$ the concentrations used were 5 and I0 $\mu \mathrm{M}$. Assays were performed in triplicate. The spontaneous revertant colonies were $34.3 \pm 4.0$; bsignificant $(P<0.05)$ reduction (\% of inhibition of mutagenicity indicated in parentheses) from revertant colonies seen with $\mathrm{NaN}_{3}, 40 \%$ or more reduction means strong antimutagenic activity; 'significant difference $(P<0.05)$ between bichalcophene concentrations; dsignificant difference $(P<0.05)$ between mononitril (A compounds) versus corresponding monocationic (B compounds).

Abbreviation: SEM, standard error of the mean. 
Table 7 Determination of anti-mutagenic activity of bichalcophenes in Salmonella typhimurium TAI535 against benzo[a]pyrene (B[a]P; $20 \mu \mathrm{M})$ in presence of $\mathrm{S} 9 \mathrm{mix}$

\begin{tabular}{|c|c|c|c|c|}
\hline \multirow[t]{3}{*}{ Compound $^{a}$} & \multicolumn{4}{|c|}{$\begin{array}{l}B[a] P \text { mutagenicity at bichalcophene concentrations } \\
\text { (revertant colonies/plate; mean } \pm \text { SEM (\% reduction in B }[\mathrm{a}] \mathrm{P} \text { mutagenicity)) }\end{array}$} \\
\hline & \multicolumn{2}{|l|}{ Pre-exposure } & \multicolumn{2}{|l|}{ Co-exposure } \\
\hline & $5 / 10 \mu \mathrm{M}$ & $10 / 20 \mu \mathrm{M}$ & $5 / 10 \mu M$ & $10 / 20 \mu \mathrm{M}$ \\
\hline$B[a] P$ & \multicolumn{4}{|c|}{$290.3 \pm 21.0(0)$} \\
\hline IA & $270.0 \pm 25.9(9)$ & $239.3 \pm 22.8(24)^{\mathrm{b}}$ & $274.0 \pm 25.2(8)$ & $240.3 \pm 27.7(23)$ \\
\hline IB & $194.7 \pm 16.6(44)^{b}$ & $153.3 \pm 5.9(64)^{b, c}$ & $207.3 \pm 17.9(38)^{\mathrm{b}}$ & $|74.3 \pm 2| .4(54)^{b}$ \\
\hline $2 \mathrm{~A}$ & $1 \mid 2.7 \pm 21.1(82)^{b}$ & $120.0 \pm 17.4(79)^{\mathrm{b}}$ & $261.0 \pm 42.7(14)$ & $264.0 \pm 30.4(12)$ \\
\hline $2 B$ & $101.7 \pm 12.1(87)^{\mathrm{b}}$ & $100.0 \pm 8.2(88)^{\mathrm{b}}$ & $256.3 \pm 14.2(16)$ & $230.7 \pm 17.6(28)$ \\
\hline $3 \mathrm{~A}$ & $264.0 \pm 6.1(12)$ & $250.0 \pm 16.5(19)$ & $267.0 \pm 21.5(\mathrm{II})$ & $255.7 \pm 27.0(16)$ \\
\hline $3 B$ & $228.0 \pm 25.2(29)^{\mathrm{b}}$ & $227.7 \pm 16.3(29)^{b}$ & $239.7 \pm 29.5(23)$ & $216.3 \pm 16.5(34)^{b}$ \\
\hline $4 \mathrm{~A}$ & $148.7 \pm 16.3(66)^{b}$ & $120.3 \pm 10.1(79)^{b}$ & $254.7 \pm 19.6(17)$ & $224.7 \pm 30.7(30)$ \\
\hline $4 \mathrm{~B}$ & I I $9.7 \pm 12.7(79)^{\mathrm{b}}$ & $108.0 \pm 9.5(85)^{\mathrm{b}}$ & $249.7 \pm 35.4(19)$ & $231.7 \pm 23.7(27)$ \\
\hline $5 \mathrm{~A}$ & $256.7 \pm 14.6(16)$ & $256.0 \pm 15.7(16)$ & $257.7 \pm 16.0(15)$ & $255.7 \pm 13.4(16)$ \\
\hline $5 B$ & $109.0 \pm 10.8(84)^{b, c}$ & $95.7 \pm 14.1(90)^{b, c}$ & $|7| .7 \pm 27.2(55)^{\mathrm{b}, \mathrm{c}}$ & $1|9.3 \pm 1| .6(79)^{b, c}$ \\
\hline
\end{tabular}

Notes: ${ }^{\mathrm{a}}$ Concentrations investigated for all compounds were 10 and $20 \mu \mathrm{M}$ except for compounds IB and $5 \mathrm{~B}-$ the concentrations used were 5 and I0 $\mu \mathrm{M}$. Assays were performed in triplicate. The spontaneous revertant colonies were $74.7 \pm 5.5$; bsignificant $(P<0.05)$ reduction $(\%$ of inhibition of mutagenicity indicated in parentheses) from revertant colonies seen with $B[a] P, 20 \%$ or less means no activity, $20 \%-40 \%$ indicates moderate activity, and $40 \%$ or more reduction means strong antimutagenic activity; 'significant difference $(P<0.05)$ between mononitril (A compounds) versus corresponding monocationic (B compounds).

Abbreviation: SEM, standard error of the mean.

Staphylococcus aureus. ${ }^{7}$ A third mechanism could be the direct interaction with the mutagens/metabolites and preventing their damaging effects. ${ }^{22}$ Since $\mathrm{B}[\mathrm{a}] \mathrm{P}$ is activated by CYP4501A1, one of the possible mechanisms would be the inhibition of this bioactivation. The antimutagenic activity of some heterocyclic aromatic amines was attributed to this mechanism..$^{23}$ However, if this is the scenario, we would expect to see no difference between the two exposure regimens (pre-exposure and co-exposure) but most bichalcophenes exerted their antimutagenic activity against $\mathrm{B}[\mathrm{a}] \mathrm{P}$ under pre-exposure conditions. In the pre-exposure protocol, bichalcophenes were incubated with the bacteria 30 minutes before the addition of $\mathrm{B}[\mathrm{a}] \mathrm{P}$. Therefore, it is possible that the antimutagenic efficiency of bichalcophenes

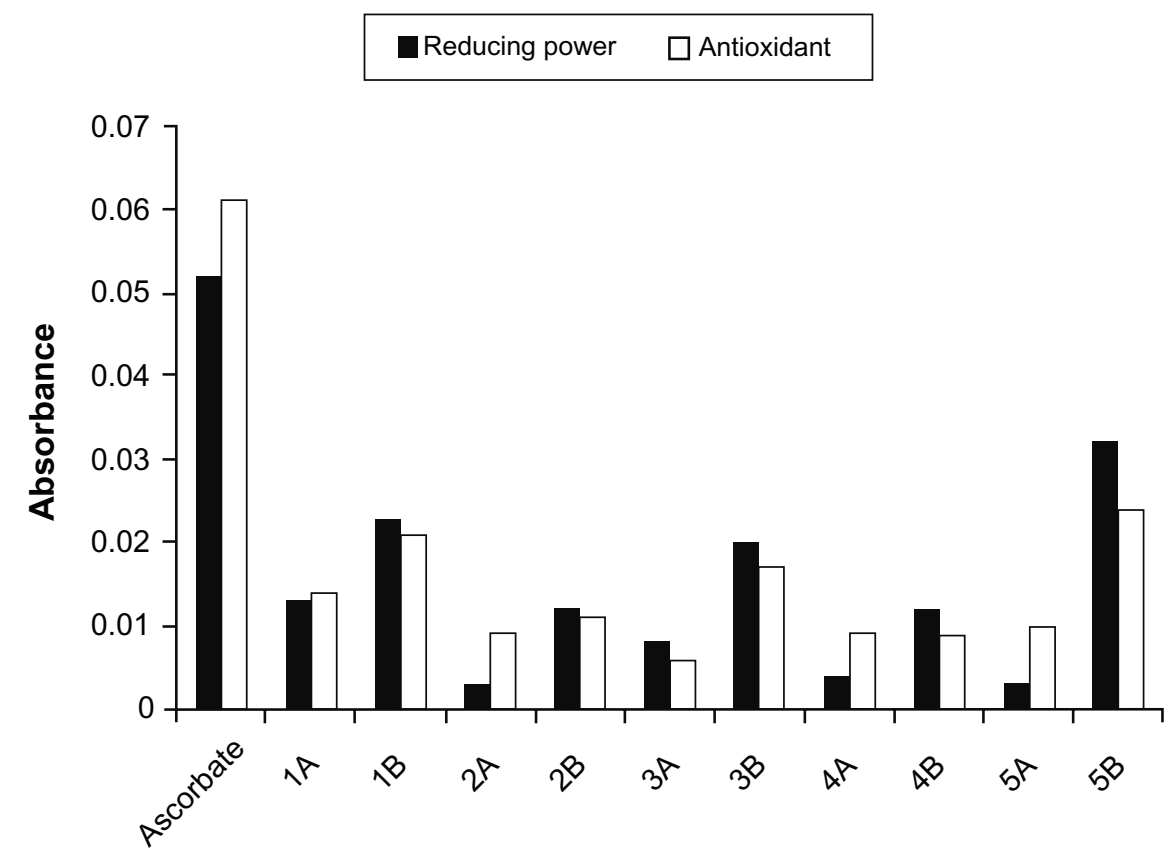

Figure 2 The reducing power and total antioxidant activity of bichalcophenes at $25 \mu \mathrm{M}$ compared to ascorbate at the same concentration. 
Table 8 Effects of bichalcophenes on sodium azide $\left(\mathrm{NaN}_{3}\right)$ mutant frequency

\begin{tabular}{|c|c|c|c|c|}
\hline \multirow[t]{3}{*}{ Compound" } & \multicolumn{4}{|c|}{ Mutant frequency and $\left(\% \text { of } \mathrm{NaN}_{3}\right)^{\mathrm{b}}$} \\
\hline & \multicolumn{2}{|c|}{ Pre-exposure } & \multicolumn{2}{|c|}{ Co-exposure } \\
\hline & $5 / 10 \mu \mathrm{M}$ & $10 / 20 \mu \mathrm{M}$ & $5 / 10 \mu M$ & $10 / 20 \mu \mathrm{M}$ \\
\hline $\mathrm{NaN}_{3}$ & \multicolumn{4}{|c|}{$10.43(100)$} \\
\hline IA & $\mathrm{I} .4 \mathrm{I}(14)^{\mathrm{a}}$ & $1.34(13)^{\mathrm{a}}$ & $1.79(17)^{\mathrm{a}}$ & $0.79(8)^{\mathrm{a}}$ \\
\hline IB & $1.07(10)^{\mathrm{a}}$ & $1.27(12)^{\mathrm{a}}$ & $0.66(6)^{a}$ & $0.56(5)^{\mathrm{a}}$ \\
\hline $2 \mathrm{~A}$ & $\mathrm{I} .44(14)^{\mathrm{a}}$ & $1.60(15)^{\mathrm{a}}$ & $1.07(10)^{\mathrm{a}}$ & $1.07(10)^{\mathrm{a}}$ \\
\hline $2 B$ & $1.32(13)^{\mathrm{a}}$ & $1.35(13)^{\mathrm{a}}$ & $1.91(18)^{\mathrm{a}}$ & $0.51(5)^{\mathrm{a}}$ \\
\hline $3 \mathrm{~A}$ & $0.97(9)^{a}$ & $1.09(10)^{\mathrm{a}}$ & $1.93(18)^{\mathrm{a}}$ & $0.89(9)^{\mathrm{a}}$ \\
\hline 3B & $1.21(12)^{\mathrm{a}}$ & $1.03(10)^{\mathrm{a}}$ & $0.87(8)^{a}$ & $0.53(5)^{\mathrm{a}}$ \\
\hline $4 \mathrm{~A}$ & $6.27(60)^{\mathrm{a}}$ & $3.00(29)^{\mathrm{a}}$ & $1.09(10)^{\mathrm{a}}$ & $1.16(11)^{\mathrm{a}}$ \\
\hline 4B & $0.88(8)^{\mathrm{a}}$ & $0.90(9)^{\mathrm{a}}$ & $2.01(19)^{a}$ & $1.89(18)^{a}$ \\
\hline $5 \mathrm{~A}$ & $\mathrm{I} .46(14)^{\mathrm{a}}$ & $2.24(21)^{\mathrm{a}}$ & $1.12(11)^{\mathrm{a}}$ & $0.74(7)^{a}$ \\
\hline $5 B$ & $1.04(10)^{\mathrm{a}}$ & $1.22(12)^{\mathrm{a}}$ & $0.62(6)^{\mathrm{a}}$ & $0.50(5)^{\mathrm{a}}$ \\
\hline
\end{tabular}

Notes: "Concentrations investigated for all compounds were 10 and $20 \mu \mathrm{M}$ except for compounds IB and $5 \mathrm{~B}$ - the concentrations used were 5 and $10 \mu \mathrm{M}$; ${ }^{\mathrm{a}}$ significant $(P<0.05)$ reduction from mutant frequency seen with $\mathrm{NaN}_{3}$; ${ }^{b}$ calculated from mutant colonies (Table 6)/viable colonies (Table 3).

against $\mathrm{B}[\mathrm{a}] \mathrm{P}$ is due to the effects on the bacteria, not on the mutagen or mutagen metabolism.

Mutation frequency is highly correlated to mutation rate. All bichalcophenes reduced the mutant frequency caused by $\mathrm{NaN}_{3}$ by $40 \%-95 \%$. Monocationic bichalcophenes were superior to the corresponding mononitriles resulting in a $95 \%$ reduction in $\mathrm{NaN}_{3}$-mutant frequency at the higher concentration investigated under the co-exposure protocol (Table 8). However, the antimutagenic activity of bichalcophenes against $\mathrm{B}[\mathrm{a}] \mathrm{P}$ mutagenicity was less evident. Most of bichalcophenes were more effective only in the pre-exposure treatment and compounds 2A, 2B, and 4B were only effective under this treatment. Under

Table 9 Effects of bichalcophenes on benzo[a]pyrene (B[a]P) mutant frequency

\begin{tabular}{|c|c|c|c|c|}
\hline \multirow[t]{3}{*}{ Compound" } & \multicolumn{4}{|c|}{ Mutant frequency and $(\% \text { of } \mathrm{B}[\mathrm{a}] \mathrm{P})^{\mathrm{b}}$} \\
\hline & \multicolumn{2}{|c|}{ Pre-exposure } & \multicolumn{2}{|c|}{ Co-exposure } \\
\hline & $5 / 10 \mu M$ & $10 / 20 \mu \mathrm{M}$ & $5 / 10 \mu M$ & $10 / 20 \mu \mathrm{M}$ \\
\hline $\mathrm{B}[\mathrm{a}] \mathrm{P}$ & \multicolumn{4}{|c|}{$4.28(100)$} \\
\hline IA & $4.33(101)$ & $3.70(86)$ & $4.40(103)$ & $3.7 \mathrm{I}(87)$ \\
\hline IB & $3.09(72)^{\mathrm{a}}$ & $2.38(56)^{\mathrm{a}}$ & $3.29(77)^{\mathrm{a}}$ & $2.7 \mathrm{I}(63)^{\mathrm{a}}$ \\
\hline $2 \mathrm{~A}$ & $1.88(44)^{\mathrm{a}}$ & $1.97(46)^{\mathrm{a}}$ & $4.35(102)$ & $4.33(101)$ \\
\hline $2 B$ & $1.56(37)^{\mathrm{a}}$ & $1.61(38)^{\mathrm{a}}$ & $3.94(92)$ & $3.72(87)$ \\
\hline $3 \mathrm{~A}$ & $4.08(95)$ & $3.85(90)$ & $4.13(96)$ & $3.93(92)$ \\
\hline $3 B$ & $3.76(88)$ & 3.81 (89) & $3.95(92)$ & $3.62(85)^{\mathrm{a}}$ \\
\hline $4 \mathrm{~A}$ & $2.30(54)^{\mathrm{a}}$ & $1.87(44)^{\mathrm{a}}$ & $3.94(92)$ & $3.49(82)^{\mathrm{a}}$ \\
\hline 4B & $1.78(42)^{\mathrm{a}}$ & $\mathrm{I} .76(4 \mathrm{I})^{\mathrm{a}}$ & $3.71(87)$ & $3.78(88)$ \\
\hline $5 \mathrm{~A}$ & $3.93(92)$ & $3.88(91)$ & $3.95(92)$ & 3.87 (9I) \\
\hline $5 B$ & $\mathrm{I} .74(4 \mathrm{I})^{\mathrm{a}}$ & $1.61(38)^{a}$ & $2.74(64)^{\mathrm{a}}$ & $2.01(47)^{\mathrm{a}}$ \\
\hline
\end{tabular}

Notes: ${ }^{\#}$ Concentrations investigated for all compounds were 10 and $20 \mu \mathrm{M}$ except for compounds IB and $5 \mathrm{~B}$ - the concentrations used were 5 and $10 \mu \mathrm{M}$; ${ }^{\mathrm{a}}$ significant $(P<0.05)$ reduction from mutant frequency seen with $\mathrm{B}[\mathrm{a}] \mathrm{P}$; ${ }^{\mathrm{b}}$ calculated from mutant colonies (Table 7)/viable colonies (Table 4). these conditions, compounds $1 \mathrm{~B}, 2 \mathrm{~B}, 4 \mathrm{~B}$, and $5 \mathrm{~B}$, in addition to $2 \mathrm{~A}$ and $4 \mathrm{~A}$, reduced the mutant frequency by $28 \%-63 \%$; while in the co-exposure protocol, compounds $1 \mathrm{~B}, 3 \mathrm{~B}, 4 \mathrm{~B}$, and $5 \mathrm{~B}$ reduced the frequency by $15 \%-53 \%$ (Table 9 ). Again monocationic (B compounds) derivatives were more effective than the analogous mononitriles (Table 9).

\section{Conclusion}

At non-toxic concentrations, bichalcophenes were not mutagenic to $S$. typhimurium. All bichalcophenes exerted strong antimutagenic activity against $\mathrm{NaN}_{3}$ and many showed antimutagenic activity against $\mathrm{B}[\mathrm{a}] \mathrm{P}$, especially in the pre-exposure conditions. This activity is most likely due to the direct effect of bichalcophenes on the bacterial DNA or the antioxidant activity of bichalcophenes rather than the interference in the bioactivation and metabolism of the mutagens. Although there are some differences in specificity between the human and bacterial systems in the response to $\mathrm{B}[\mathrm{a}] \mathrm{P}$ mutagenic effects and in the processing of DNA adducts formed, this survey in the Salmonella system is of essential help as a platform to select compounds for further investigations. Monocationic B compounds were superior to the equivalent mononitrile A compounds. Out of the ten bichalcophenes, it is important to select the prime compounds for the time consuming and costly chemoprevention studies in animal models. The National Cancer Institute (Developmental Therapeutics Program) has recently examined these bichalcophenes for anticancer activity in the 58 cell line in the concentration range defined in the present study and found that the most active compounds we identify in the present study $(1,4$, and 5B) were the most active compounds in the NCI study (unpublished data).

Based on the results of the present investigation, monocationic compounds $(1,4$, and $5 \mathrm{~B})$ will be selected for further in vivo anticancer studies.

\section{Acknowledgments}

The authors acknowledge Dr Mohamed Ismail of King Faisal University for providing the bichalcophene compounds. This project was supported by King Faisal University, Deanship of Scientific Research, Grant 130156.

\section{Disclosure}

The authors report no conflicts of interest in this work.

\section{References}

1. Maron DM, Ames BN. Revised methods for the Salmonella mutagenicity test. Mutat Res. 1983;113(3-4):173-215. 
2. Jarak I, Marjanovic' M, Piantanida I, Kralj M, Karminski-Zamola G. Novel pentamidine derivatives: synthesis, antitumor properties and polynucleotide-binding activities. Eur J Med Chem. 2011;46(7):2807-2815.

3. Kobayashi J, Kato A, Ota Y, Ohba R, Komatsu K. Bisbenzamidine derivative, pentamidine represses DNA damage response through inhibition of histone H2A acetylation. Mol Cancer. 2010;9: 34-44.

4. Paliwal SK, Verma AN, Paliwal S. Neglected disease - african sleeping sickness: recent synthetic and modeling advances. Sci Pharm. 2011;79(3):389-428.

5. Youssef MM, Al-Omair MA, Ismail MA. Synthesis, DNA affinity, and antimicrobial activity of 4-substituted phenyl-2,20-bichalcophenes and aza-analogues. Med Chem Res. 2012;21(12):4074-4082.

6. Hussin WA, Ismail MA, El-Sayed WM. Novel 4-Substituted Phenyl-2,2' Bichalcophenes and Aza-Analogues as Antibacterial Agents: Structural Activity Relationship. Drug Des Devel Ther. In press.

7. El-Sayed WM, Hussin WA, Ismail MA. Efficacy of two novel 2,2'bifurans to inhibit methicillin-resistant Staphylococcus aureus infection in male mice in comparison to vancomycin. Drug Des Devel Ther. 2012;6:279-287.

8. Luch A, Baird WM. Metabolic activation and detoxification of polycyclic aromatic hydrocarbons. In: Luch AA, editor. The Carcinogenic Effects of Polycyclic Aromatic Hydrocarbons. London: Imperial College Press; 2005:19-96.

9. Yoon JH, Besaratinia A, Feng Z, et al. DNA damage, repair, and mutation induction by (+)-Syn and (-)-anti-dibenzo[a,1]pyrene-11,12-diol13,14-epoxides in mouse cells. Cancer Res. 2004;64(20):7321-7328.

10. Tesfai Y, Davis D, Reinhold D. Chromium can reduce the mutagenic effects of benzo[a]pyrenediolepoxide in normal human fibroblasts via an oxidative stress mechanism. Mutat Res. 1998;416(3):159-168.

11. Katoh Y, Nemoto N, Tanaka M, Takayama S. Inhibition of benzo[a] pyrene-induced mutagenesis in Chinese hamster V79 cells by hemin and related compounds. Mutat Res. 1983;121(2):153-157.

12. Neffati A, Limem I, Kilani S, et al. A comparative evaluation of mutagenic, antimutagenic, radical scavenging and antibacterial activities of essential oils of Pituranthos chloranthus (Coss et Dur). Drug Chem Toxicol. 2009;32(4):372-380.
13. Ajith T, Subin JP, Jacob J, Sanjay PS, Babitha NV. Antimutagenic and anti-oxidant activities of the non-steroidal anti-inflammatory drug celecoxib. Clin Exp Pharmacol Physiol. 2005;32(10):888-893.

14. Hong CE, Cho MC, Jang HA, Lyu SY. Mutagenicity and anti-mutagenicity of Acanthopanax divaricatus var albeofructus. JToxicol Sci. 2011;36(5): 661-668.

15. Prieto P, Pineda M, Aguilar M. Spectrophotometric quantitation of antioxidant capacity through the formation of a phosphomolybdenum complex: Specific application to the determination of vitamin E. Anal Biochem. 1999;269(2):337-341.

16. Oyaizu M. Studies on products of browning reaction: Antioxidative activity of product of browning reaction prepared from glucosamine. Jpn J Nutr. 1986;44:307-315.

17. Zeiger E. Identification of rodent carcinogens and noncarcinogens using genetic toxicity tests: Premises, promises, and performance. Regul Toxicol Pharmacol. 1998;28:85-95.

18. Stauffert I, Paulini H, Steinmann U, Sippel H, Estler CJ. Investigations on mutagenicity and genotoxicity of pentamidine and some related trypanocidal diamidines. Mutat Res. 1990;245(2):93-98.

19. Connor TH, Trizna Z. Pentamidine isethionate is negative in tests for microbial mutagenicity and chromosomal breakage in vitro. Toxicol Lett. 1992;63(1):69-74.

20. Marnewick JL, Gelderblom WC, Joubert E. An investigation on the antimutagenic properties of South African herbal teas. Mutat Res 2000;471(1-2):157-166.

21. Collins AR, Azqueta A, Langie SA. Effects of micronutrients on DNA repair. Eur J Nutr. 2012;51(3):261-279.

22. Watanabe M, Kobayashi H, Ohta T. Rapid inactivation of 3-chloro-4(dichloromethyl)-5-hydroxy-2 $(5 \mathrm{H})$-furanone $(\mathrm{MX})$, a potent mutagen in chlorinated drinking water, by sulfhydryl compounds. Mutat Res. 1994;312(2):131-138.

23. Schwab CE, Huber WW, Parzefall W, et al. Search for compounds that inhibit the genotoxic and carcinogenic effects of heterocyclic aromatic amines. Crit Rev Toxicol. 2000;30(1):1-69.

\section{Publish your work in this journal}

Drug Design, Development and Therapy is an international, peerreviewed open-access journal that spans the spectrum of drug design and development through to clinical applications. Clinical outcomes, patient safety, and programs for the development and effective, safe, and sustained use of medicines are a feature of the journal, which

\section{Dovepress}

has also been accepted for indexing on PubMed Central. The manuscript management system is completely online and includes a very quick and fair peer-review system, which is all easy to use. Visit http://www.dovepress.com/testimonials.php to read real quotes from published authors. 